\title{
Zpráva o záchranném výzkumu mladopaleolitického sídliště v Hlinsku u Lipníka nad Bečvou
}

\author{
Field report of a rescue excavation of an Upper Palaeolithic \\ settlement in Hlinsko near Lipník nad Bečvou \\ (Moravia, Czech Republic) \\ - Ondřej Mlejnek* -
}

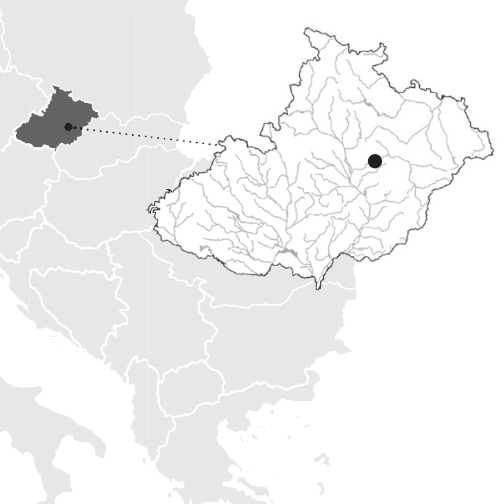

\section{KEYWORDS:}

Central Moravia - Upper Palaeolithic - Aurignacian - settlement rescue excavation - lithics

\section{ABSTRACT}

This article presents the results of a 2019 rescue excavation of an Upper Palaeolithic settlement at Kouty III in Hlinsko u Lipníka in Central Moravia. The excavation took place due to a planned enlargement of the local greywacke mine. Lithic artefacts were found in Quaternary sediments redeposited by slope processes. The density of artefacts was quite low; therefore, it was not possible to recover them using a standard archaeological excavation and most of them were collected on the mounds of dirt beside the trenches excavated by a mechanical excavator, or during an excavation of the Eneolithic barrows situated in the south-western part of the site.

A total of 106 lithic pieces were found during this excavation. Eighteen of the artefacts lacked a patinated surface, thus they were attributed to the Eneolithic period. A collection of 88 patinated lithics was classified as Aurignacian based on technological and typological characteristics. Most of the artefacts were made on erratic flint, however radiolarite, quartzite, spongolite and Moravian Jurassic chert were present as well. The technology was based on production of blades and bladelets from Upper Palaeolithic prismatic cores. These bladelets could have been used as components of composite tools. One tool set is similar to the neighbouring site Kouty I (Škrdla 2007) and consists of nine burins, three splintered pieces, one thick end scraper and two tool fragments. A bifacial triangular point that was found at Kouty I (Demidenko et al. 2018) and at several other surface sites in the surrounding area, were not found here. Despite this fact it is possible to classify this site as Evolved Aurignacian of the so-called Morava River type (Klíma 1978), which is quite common in this region.

\footnotetext{
* Corresponding author - E-mail address: mlejnek.o@seznam.cz
}

\section{1. Úvod}

Ve dnech 13. 5. - 15. 8. 2019 proběhl na katastru obce Hlinsko u Lipníka nad Bečvou záchranný archeologický výzkum Archeologického centra Olomouc vyvolaný plánovaným rozšířením kamenolomu Podhůra. Zkoumaná plocha o výměře $35000 \mathrm{~m}^{2} \mathrm{se}$ nacházela v trati Kouty v nadmořské výšce 300-340 m n. m. Asi 350 m západním směrem od této polohy byly roku 2005 povrchovým sběrem objeveny paleolitické artefakty a v roce 2006 zde proběhl záchranný archeologický výzkum Archeologického ústavu v Brně pod vedením Petra Škrdly (Škrdla 2006; 2007; Demidenko et al. 2018; Šebela a kol. 2007, 31-47). Tento výzkum zde odkryl soubor 103 kusů štípané industrie autory řazený do rámce pomoravského aurignacienu (poprvé definován B. Klímou v roce 1978 na základě souboru z Přestavlk u Přerova). Zajímavými nálezy zde byly zejména listovitý hrot trojúhelníkového tvaru typu Lhota vyrobený ze silicitu z glacigenních sedimentů a zlomek jednostranně retušovaného hrotu, původně snad stejného tvaru. Několik podobných hrotů, pojmenovaných podle povrchové lokality na katastru sousední obce Lhota u Lipníka, bylo nalezeno také na dalších stejně datovaných povrchových lokalitách v okolí. Záchranný výzkum zde pokračoval ještě i v roce 2008 a přinesl nálezy dalších 33 paleolitických artefaktů (Figel' et al. 2009, 227). P. Škrdla nazval tuto polohu Kouty I. V roce 2005 nalezl Dalibor Figel' místně retušovaný patinovaný úštěp ze silicitu z glacigenních sedimentů v poloze označené jako Kouty II, která se nachází na poli asi 300 m jihozápadně od popisované lokality. V roce 2008 zde ještě P. Škrdla a Z. Schenk nalezli radiolaritové škrabadlo (Figel' et al. 2009, 227-228). $\mathrm{Z}$ těchto důvodů byla nově zkoumaná plocha nazvána Kouty III. Vzhledem k velké výměře plochy s nálezy je ale pravděpodobné, že se spíše, než o jednorázové sídliště, jedná o klastr lokalit, opakovaně navštěvovaný paleolitickými lidmi, a že rozdělení polohy Kouty na dílčí lokality I, II a III je dáno spíše historií výzkumu než vlastní nálezovou situací. Povrchové sběry navíc dokazují, že paleolitické osídlení hrany kry Maleníku pokračuje oběma směry a že je někdy téměř nemožné určit, kde jedna lokalita končí a jiná začíná (srov. Figel' et al. 2009, 226).

Zkoumaná lokalita se nachází na hraně kry Maleníku (součást Podbeskydské pahorkatiny a oblasti tzv. Záhoří) s dobrým výhledem na jižní část Moravské brány (obr. 1 a 2). Do jihozápadní části zkoumané plochy zasahoval dvěma mohylami eneolitický mohylník kultury se šňůrovou keramikou a bošácké skupiny, který snad souvisí s poslední fází existence blízkého pravěkého hradiště v poloze Hradištko, odkud mimochodem také pocházejí paleolitické artefakty (Pavelčík 2001; Šebela a kol. 2007; Škrdla 2006). Tyto dvě mohyly byly postupně prozkoumány a výsledky výzkumu jsou popsány V. Hadravou $\mathrm{v}$ tomto svazku v kapitole věnované eneolitu. Zejména plášt 


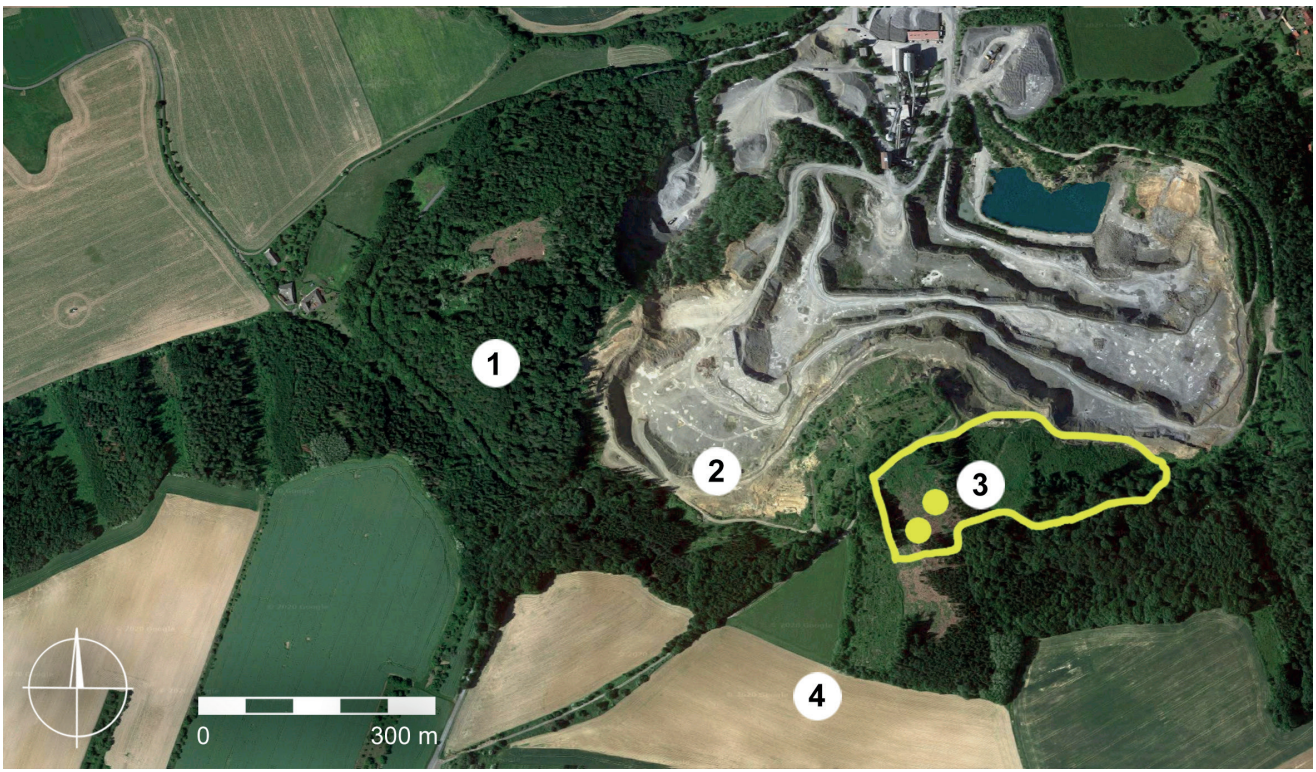

Obr. 1. Hlinsko. Letecká fotografie lomu Podhưra a okolís vyznačením jednotlivých poloh s paleolitickými nálezy. 1 - Hradišt'ko, 2 - Kouty I, 3 - Kouty II, 4 - Kouty III. Žlutá kolečka označují polohu zkoumaných eneolitických mohyl. Žlutá linie vymezuje plochu lokality Hlinsko-Kouty III zkoumanou vrámci záchranného archeologického výzkumu v roce 2019. Zpracoval O. Mlejnek.

Fig. 1. Hlinsko. An aerial view of the Podhuira mine with the location of particular Palaeolithic sites. 1 - Hradišt'ko, 2 - Koutyl, 3 - Kouty II, 4 - Kouty III. Yellow circles mark the location of the excavated Eneolithic barrows. Yellow line delimits an area of the Hlinsko - Kouty III site researched in the frame of a rescue archaeological excavation in 2019. Created by O. Mlejnek.

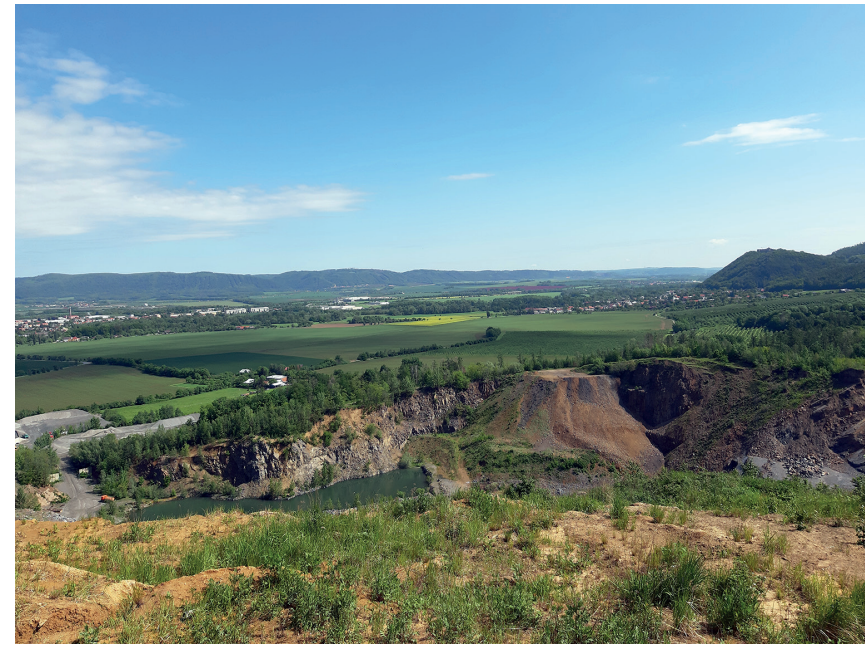

Obr. 2. Hlinsko. Pohled na lom Podhůra a do jižního ústí Moravské brány z lokality Hlinsko - Kouty III. Foto O. Mlejnek.

Fig. 2. Hlinsko. A view of the Podhưra mine and the southern part of the Moravian Gate from the Hlinsko - Kouty III site. Photo by O. Mlejnek.

druhé, větší mohyly poskytl také několik kusů patinované štípané industrie paleolitického stáří. Další paleolitické artefakty byly nalezeny na skryté ploše v okolí mohyl. Původně se zde nacházel vzrostlý les, který byl v průběhu posledních patnácti let vykácen, o čemž svědčily zbytky pařezů, kořeny a pozůstatky ohništ', ve kterých byly páleny větve pokácených stromů.

\section{Metodika výzkumu a stratigrafie}

Vzhledem k velké rozloze plochy určené k odtěžení nebylo možné provést souvislou skrývku, a už vůbec ne prokopat všechny sedimenty, které by mohly obsahovat paleolitické artefakty. Poté, co se podařilo najít tři artefakty prímo v profilu lomu, byla v místě nálezů dvou kusů štípané industrie vyhloubena sonda, která však nepřinesla další nálezy. Sedimenty pocházející z této sondy jsme se pokusili rozplavit za pomoci přivolané cisterny, nevedlo to ale opět k výraznějším úspěchům. Proto bylo rozhodnuto vyhloubit na zkoumané lokalitě několik sond bagrem, které postupně pokryly v pravidelných odstupech celou plochu. Ojedinělé artefakty byly poté nalezeny prrímo v sondách. Nacházely se na bázi vrstvy tvořené odvápněným sprašovým sedimentem. Zřejmě se jednalo o přemístěné svahové sedimenty kvarterního stárí, které vyplňovaly mělké deprese v podložních terciérních štěrkopíscích a jílovitých sedimentech (obr. 3). Mocnost těchto sedimentů byla značně variabilní. Místy tvořily až $80 \mathrm{~cm}$ hluboké kapsy, jindy úplně vyznívaly a terciérní sedimenty vystupovaly až téměř k povrchu, kde je překrývala pouze mělká vrstva lesní půdy. Většina artefaktů byla ale nalezena po dešti na haldách sond, případně na skryté ploše kolem zkoumaných mohyl. Několik nálezů pochází také př́ímo z násypů eneolitických mohyl, kam se druhotně dostaly, a také ze slabé vrstvy sprašových svahových sedimentů dochovaných pod mohylami (viz letecký snímek plochy lokality s plošnou distribucí nálezů - obr. 6).

\section{Popis nálezů}

Soubor štípané industrie získané v rámci záchranného výzkumu čítal celkem 106 artefaktů, z nichž osmnáct bylo na základě absence patiny přiřazeno do eneolitu. Problematickou je z tohoto hlediska křemencová složka souboru, která nepatinuje. Z okolních lokalit víme, že křemenec typu sluňák využívali v této oblasti pravěcí lidé od paleolitu až po eneolit. Masivní křemencové globulární jádro a několik dalších úštěpů, které byly nalezeny v plášti eneolitických mohyl a v jejich blízkosti, je možné přiřadit spíše k eneolitické složce souboru, zatímco tři sluňákové úštěpy nalezené v severní části lokality v blízkosti paleolitických artefaktů mohou být datovány spíše do paleolitu. Pochybnosti ohledně datování se týkají také několika přepálených a radiolaritových artefaktů. $\mathrm{V}$ rámci paleolitického souboru bylo nakonec hodnoceno celkem 88 artefaktů. Jeden artefakt ze silně přepáleného silicitu z glacigenních sedimentů byl navíc nalezen při povrchovém sběru na sousední poloze Kouty I, která byla zkoumána záchranným archeologickým výzkumem v roce 2006 (Škrdla 2007). Jedná se o zlomek blíže neurčitelného retušovaného nástroje. Následující text bude věnován stručnému zhodnocení paleolitické části souboru štípané industrie z polohy Hlinsko - Kouty III. 


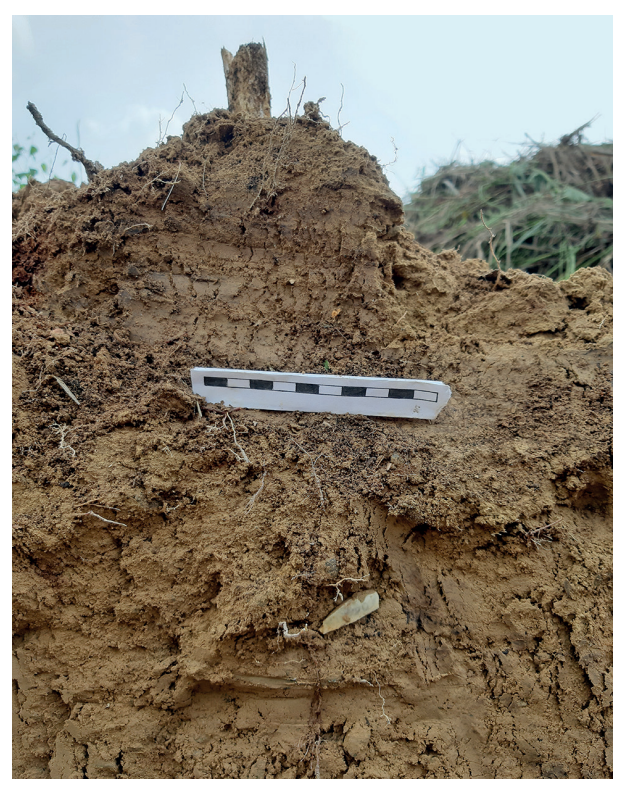

Obr. 3. Hlinsko. Artefakt nalezený in situ v profilu bagrem vyhloubené sondy na lokalitě Hlinsko - Kouty III. Foto O. Mlejnek.

Fig. 3. Hlinsko. An artefact found in situ in a section of a trench excavated by a mechanical excavator at the Hlinsko - Kouty III site. Photo by O. Mlejnek.

\subsection{Suroviny}

Kamenné suroviny nalezených artefaktů (tab. 1) byly určeny převážně makroskopicky (viz Přichystal 2009). Několik hůře rozpoznatelných artefaktů bylo prohlédnuto ve vodní imerzi pod stereomikroskopem a následně určeno A. Přichystalem. Ze surovinového hlediska výrazně převažovaly silicity z glacigenních sedimentů (SGS, 70 ks, 79,5\%), jejichž nejbližší výchozy se nacházejí asi 25 km severovýchodně od lokality. Druhou nejčastěji zastoupenou surovinou byl radiolarit typu Vršatské Podhradie ( $5 \mathrm{ks}, 5,7 \%$ ), původem z asi $62 \mathrm{~km}$ jihovýchodním směrem vzdáleného Vlárského průsmyku na hranicích Moravy a Slovenska. Další zastoupené suroviny je již možné sbírat v místních štěrcích. Jedná se o kř́ídový spongolit, moravské jurské rohovce a již zmíněný křemenec typu sluňák (vše po 3 ks, 3,4\%). Nejisté ojedinělé artefakty jsou vyrobeny z blíže neurčitelného místního rohovce, křemene, šedého nevápnitého prachovce a z valounu chalcedonové hmoty.

\begin{tabular}{llc}
\hline SUROVINY & počet & $\%$ \\
\hline silicity z glacigenních sedimentů & 70 & 79,5 \\
\hline radiolarit & 5 & 5,7 \\
\hline moravské jurské rohovce & 3 & 3,4 \\
\hline spongolit & 3 & 3,4 \\
\hline sluňák & 3 & 3,4 \\
\hline jiné & 4 & 4,6 \\
celkem & 88 & 100
\end{tabular}

Tab. 1. Hlinsko - Kouty III. Suroviny zastoupené v analyzovaném souboru. Tab. 1. Hlinsko - Kouty III. Raw material composition of the analysed lithic assemblage.

\subsection{Technologie}

Z technologického hlediska (tab. 2) je zajímavé poměrně vysoké zastoupení jader (14 ks, 15,9 \%, tab. 3). Objevují se mezi nimi zejména prismatická jednopodstavová, méně často dvojpodstavová typická mladopaleolitická jádra (7 ks, obr. 5: 2-5). Dále se vyskytla dvě jádra nepravidelného tvaru, jedno tužkovité (obr. 4: 10) a jedno klínové jádro (obr. 5: 6). Na jádrových kusech byly také vyrobeny čtyři nástroje (dva odštěpovače a dvě rydla, obr. 4: 11 a 20 a obr. 5: 3 a 7). Na základě negativů na těžních plochách jader se jednalo o jádra určená k těžbě úštěpů ( $8 \mathrm{ks})$ nebo čepelek (3 ks). Jádra jsou většinou drobná, ve vysokém stupni vytěžení a opuštěna byla často na základě technologické chyby (zalomení nebo vyběhnutí úštěpu), která znemožnila další těžbu. Na základě studia jader se zdá, že cílem zdejších výrobců paleolitické štípané industrie byla př́prava čepelových jader prismatického tvaru, ze kterých byly následně těženy čepele (viz prítomnost typické spongolitové čepele $\mathrm{z}$ hrany jádra v souboru, obr. 4: 15, a zlomku další čepele z hrany jádra ze silicitu z glacigenních sedimentů, obr. 4: 18), po redukci velikosti jádra čepelky, mikročepele a nakonec i drobné úštěpy, až do jejich úplného vytěžení. Objevují se také jádra na masivních úštěpech, některé kusy plynule přechází do polyedrických rydel, př́ipadně vysokých škrabadel (obr. 4: 21), která zřejmě funkčně sloužila také jako jádra k těžbě čepelek a mikročepelí. V debitáži převažují úštěpy (35 ks, 39,8 \%) nad čepelemi (13 ks, 14,8 \%), čepelkami (7 ks, 8 \%) a mikročepelemi (4 ks, 4,5\%). Převaha ale není nijak výrazná. Úštěpy byly zřejmě odbíjeny zejména ve fázi př́pravy jader a také $\mathrm{v}$ konečné fázi jejich exploatace. Finálními produkty ale zřejmě byly čepele (obr. $4: 8$ a 9), čepelky (obr. 4:2, 4 a 5) a mikročepele (obr. 4: 7), které byly následně zasazovány podélně vedle sebe do násad $\mathrm{z}$ organických materiálů (dřevo, kost), čímž vznikaly složené nástroje, které mohly být používány např́íklad při řezání nebo jako projektily. Retušované čepelky a mikročepele se ale v souboru neobjevují, což platí i o sousední lokalitě Kouty I (Škrdla 2007, 312). Poslední zastoupenou technologickou kategorií v souboru jsou blíže neurčitelné zlomky (15 ks, $17 \%)$.

Patky u celých a proximálních kusů debitáže jsou většinou ploché (12 ks), méně často fasetované (8 ks), vzácně se objevily patky lineární $(2 \mathrm{ks})$, bodové $(2 \mathrm{ks})$ a diedrické (1 ks). V kombinaci s př́itomností výraznějších i méně výrazných bulbů a římsiček a s ostrými úhly, které svírají úderové a těžní plochy jader, to svědčí pro používání metody př́ímého úderu tvrdým otloukačem při přípravě jader a měkkým otloukačem (měkký kámen, paroh, kost) při vlastní těžbě polotovarů a při retušování nástrojů.

\begin{tabular}{lll}
\hline TECHNOLOGICKÉ KATEGORIE & počet & $\%$ \\
\hline zlomky & 15 & 17 \\
\hline jádra & 14 & 15,9 \\
\hline úštěpy & 35 & 39,8 \\
\hline čepele & 13 & 14,8 \\
\hline čepelky & 7 & 8 \\
\hline mikročepele & 4 & 4,5 \\
celkem & 88 & 100
\end{tabular}

Tab. 2. Hlinsko - Kouty III. Zastoupení jednotlivých technologických kategorií vanalyzovaném souboru.

Tab. 2. Hlinsko - Kouty III. Composition of individual technological categories in the analysed lithic assemblage. 

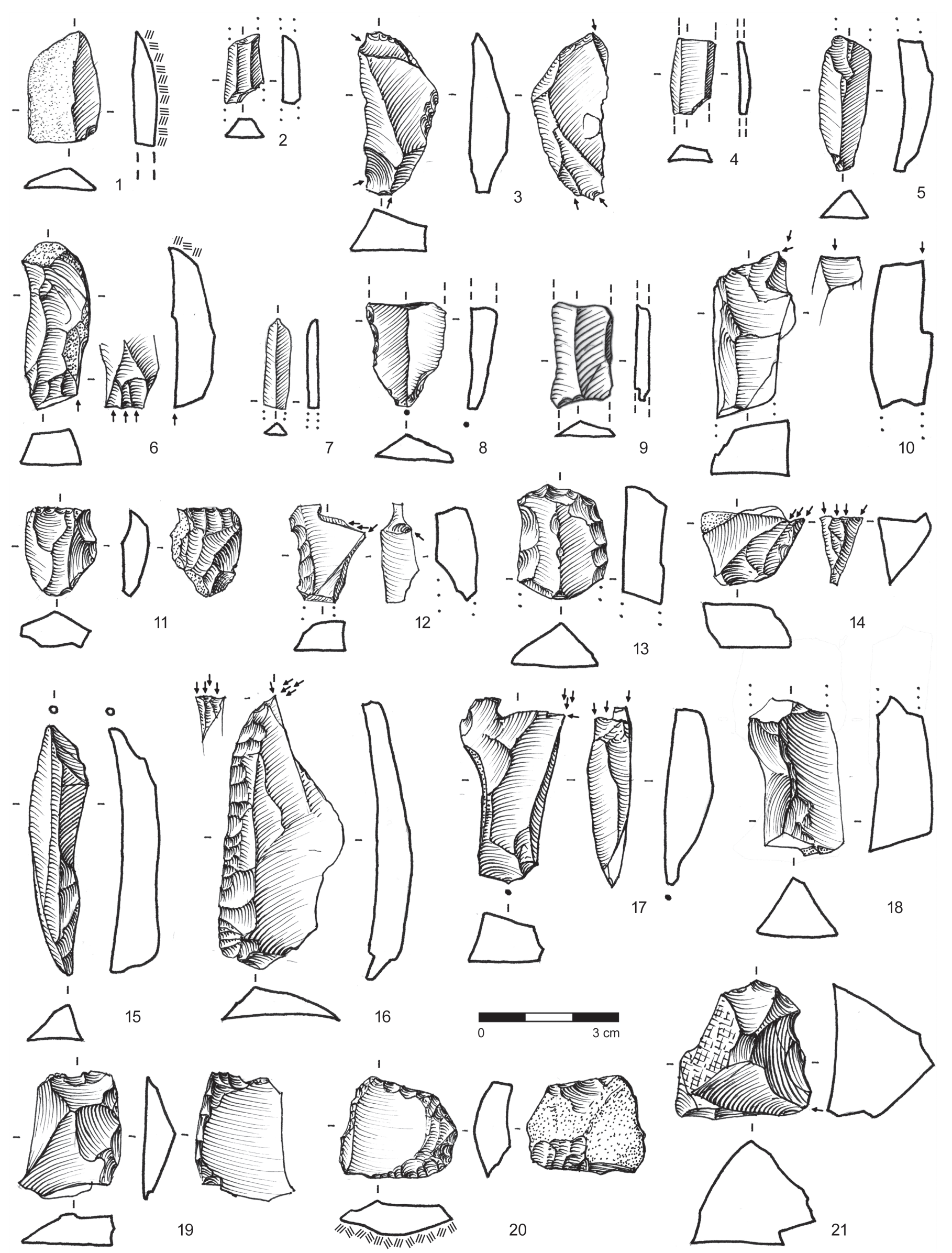

Obr. 4. Hlinsko - Kouty III. Výběr z nalezených artefaktů. Kresba L. Dvořáková, O. Mlejnek.

Fig. 4. Hlinsko - Kouty III. Selected artefacts. Drawings by L. Dvořáková, O. Mlejnek. 

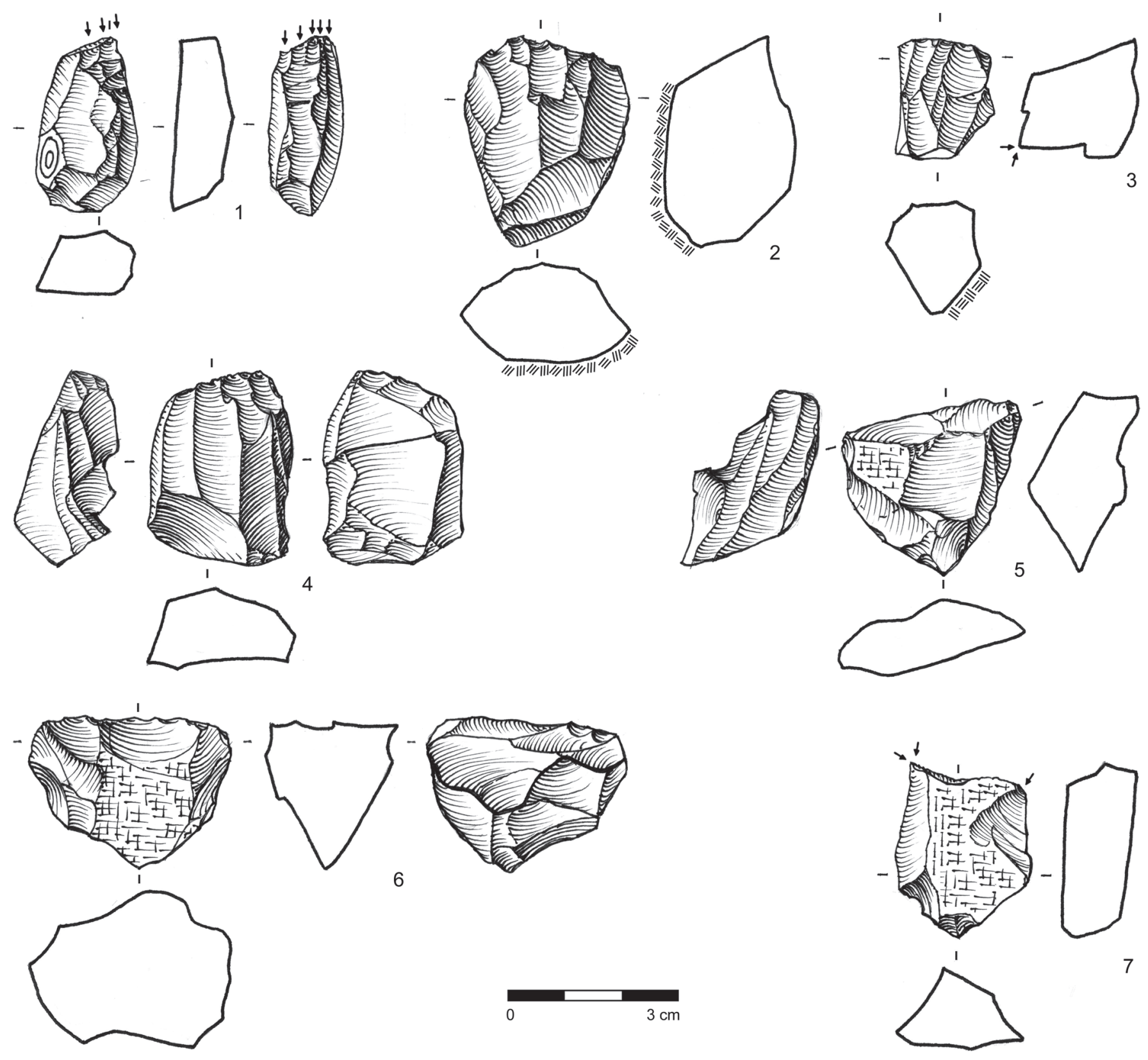

Obr. 5. Hlinsko - Kouty III. Výběr z nalezených artefaktů. Kresba L. Dvořáková, O. Mlejnek.

Fig. 5. Hlinsko - Kouty III. Selected artefacts. Drawings by L. Dvořáková, O. Mlejnek.

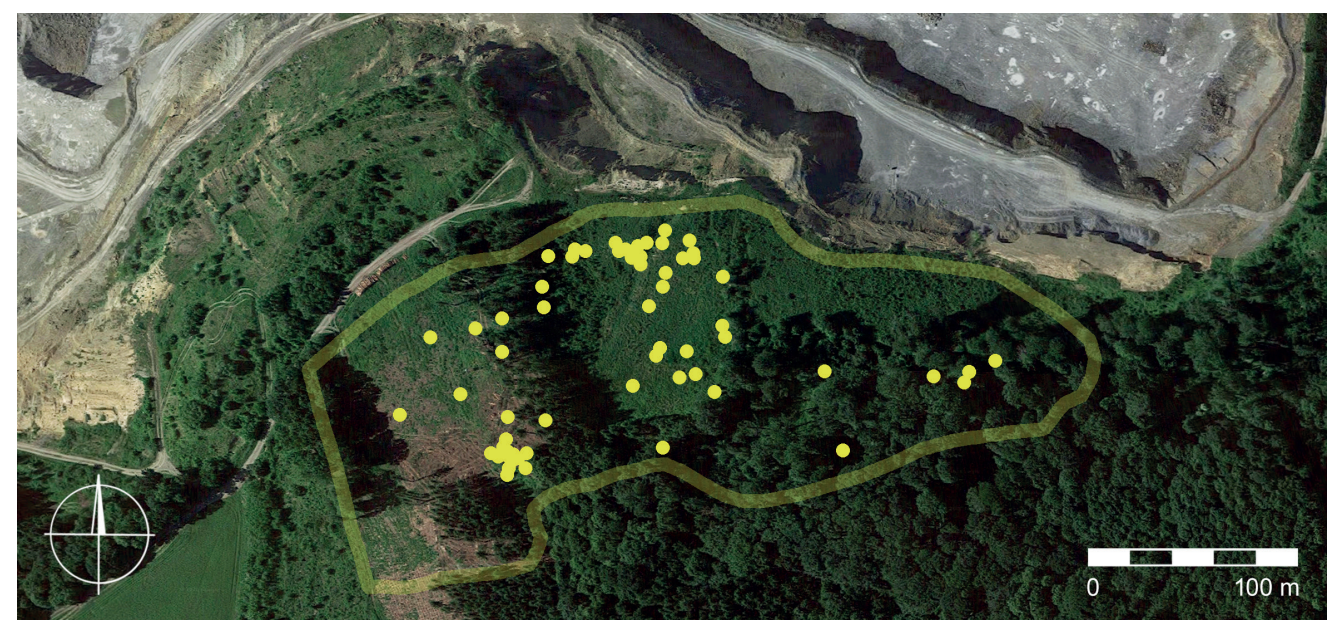

Obr. 6. Hlinsko - Kouty III. Letecký snímek lokality s místy nálezů

jednotlivých artefaktů (žluté body). V programu Google Earth Pro zpracoval O. Mlejnek.

Fig. 6. Hlinsko - Kouty III. Aerial view of the site with find places of particular artefacts (yellow dots). Created by O. Mlejnek in the Goog/e Earth Pro programme. 


\begin{tabular}{|c|c|c|c|c|c|c|c|}
\hline inv. č. & tvar jádra & počet podstav & míra vytěžení & negativy & poznámka & surovina & obr. \\
\hline 13 & prismatické & jednopodstavové & těžené & čepelky & & SGS & $5: 2$ \\
\hline 16 & nepravidelné & jednopodstavové & těžené & úštěpy & pův. snad masivní úštěp & radiolarit & - \\
\hline 20 & prismatické & dvojpodstavové & zbytkové & čepelky & & SGS & $5: 4$ \\
\hline 27 & klínové & dvojpodstavové & těžené & úšstěpy & & SGS & $5: 6$ \\
\hline 37 & nepravidelné & jednopodstavové & těžené & úštěpy & jádro na menší hlíze & SGS & - \\
\hline 40 & & & & & odštěpovač & SGS & 4: 20 \\
\hline 43 & prismatické & jednopodstavové & těžené & čepelky & těžba z užší strany jádra & SGS & $5: 5$ \\
\hline 45 & & & & & klínové rydlo boční & SGS & $5: 7$ \\
\hline 54 & prismatické & neurčitelné & zbytkové & úšstěpy & přepálený zbytek jádra & SGS & - \\
\hline 56 & prismatické & jednopodstavové & těžené & úštěpy & zalomený negativ úštěpu & SGS & - \\
\hline 60 & prismatické & jednopodstavové & zbytkové & úštěpy & klínové rydlo na jadérku & SGS & $5: 3$ \\
\hline 73 & tužkovité & jednopodstavové & těžené & úštěpy & na masivním úštěpu & SGS & 4: 10 \\
\hline 75 & & & & & odštěpovač & SGS & 4: 11 \\
\hline 84 & prismatické & jednopodstavové & zkouška & úštěpy & nejistý artefakt & prachovec & - \\
\hline
\end{tabular}

Tab. 3. Hlinsko -Kouty III. Soupis nalezených jader včetně jádrových nástrojů.

Tab. 3. Hlinsko - Kouty III. A list of the excavated cores with core tools included.

\subsection{Typologie}

Soubor nástrojů (tab. 4) je tvořen celkem patnácti artefakty. Jako polotovary pro jejich výrobu sloužily jak úštěpy ( $5 \mathrm{ks})$, tak i jádra (4 ks), čepele (3 ks) a zlomky (3 ks). Rydla (9 ks) výrazně převažují nad škrabadly (1 ks). Převažují polyedrická rydla klínová, někdy až oblouková (obr. 4: 6, 12 a 17), objeví se i jádrová rydla (obr. 5: 1, 3 a 7) a rydla plochá (obr. 4: 3 a 6). Funkčně zřejmě většina rydel sloužila jako jádra $\mathrm{k}$ výrobě čepelek a mikročepelí a tvarově také do jader plynule přecházejí. Zajímavý je nález polyedrického klínového rydla na čepeli s laterální zabíhající retuší, které je vyrobeno z téměř nepatinovaného silicitu z glacigenních sedimentů (obr. 4: 16). Není tedy jisté, jestli se nejedná o eneolitickou příměs. $V$ př́padě jediného nalezeného škrabadla se jedná o vysoké škrabadlo na zlomku retušované čepele, nikoliv však o typické aurignacké kýlovité škrabadlo s lamelární retuší (obr. 4: 13). Soubor nástrojů doplňují tři odštěpovače, z nichž dva jsou vyrobeny z jádrových kusů (obr. 4: 11 a 20) a jeden z reparačního úštěpu (obr. 4: 19), a dva blíže neurčitelné zlomky. První přepálený zlomek nástroje mohl být snad původně další vysoké škrabadlo a druhý zlomek patinovaného silicitu z glacigenních sedimentů snad pochází z kýlovitého škrabadla rozpadlého mrazem, nebo polyedrického rydla.

\section{Diskuze}

Většina artefaktů je silně patinovaná a někdy mají i navětralý povrch, což svědčí o tom, že musely ležet delší dobu na povrchu. Některé artefakty jsou ale patinovány méně, někdy i jemně nebo nestejnoměrně, takže zřejmě musely být nedlouho po výrobě překryty sedimentem. Celkem se v souboru objevilo patnáct více či méně přepálených artefaktů, což svědčí o přítomnosti ohništ na zkoumaném paleolitickém sídlišti. V budoucnu by to snad mohlo také umožnit termoluminiscenční datování nálezů.

Vzhledem $\mathrm{k}$ př́tomnosti aurignackých typů nástrojů (polyedrická, někdy až oblouková rydla, např. obr. 4: 14) a jader (prismatická čepelková jádra, např. obr. 5: 4) je možné soubor zařadit do rámce vyvinutého, snad pozdního aurignacienu. Přestože zde, na rozdíl od blízké polohy Kouty I, chybí nález plošně retušovaného trojúhelníkového hrotu typu Lhota, můžeme tento soubor na základě dalších znaků zařadit do rámce pomoravského aurignacienu s hroty typu Lhota.
Vzhledem k velké rozloze plochy, na které jsou paleolitické artefakty nalézány, je na zvážení, zda se jedná společně s polohami Kouty I a Kouty II o jednu lokalitu, nebo spíše o klastr paleolitickými lovci opakovaně navštěvovaných dočasných sídlišť. Pravděpodobně platí to druhé, přičemž díky bohatým nálezům pocházejícím z povrchových sběrů víme, že polohy s paleolitickými lokalitami s podobnou aurignacoidní industrií se nacházejí na kře Maleníku i na jiných místech na katastru obce Hlinsko (Figel', Schenk, Škrdla 2009), ale i sousedních obcí Lhota, Pavlovice a Kladníky (viz např. Klíma 1978; 1979; 1980; Fryč 1981; Přichystal 1980, Jelínková 2005; Šebela a kol. 2007, 40-45; Diviš, Fryč 2011, 123). Původní střed lokality s největší hustotou nálezu se původně patrně nacházel na temeni dnes již odtěženého návrší, které se nacházelo asi 200 m severně od zkoumané lokality. Paleolitické lovce a sběrače sem zřejmě nalákal skvělý výhled severozápadním směrem na jižní část Moravské brány (viz obr. 2), která tvoří přirozenou spojnici Podunají a moravských úvalů na jihu se Středoevropskou nížinou na severu, a právě tudy zřejmě musela táhnout početná stáda lovné zvěře.

\section{Závěr}

Článek popisuje soubor aurignacké štípané industrie získané v rámci záchranného archeologického výzkumu v poloze Hlinsko Kouty III. Společně s dalšími mladopaleolitickými soubory získanými v poloze Kouty (Škrdla 2006; 2007; Figel’ et al. 2009; Šebela a kol. 2007, 31-47) svědčí o zde situovaném klastru opakovaně navštěvovaných lokalit, které je možné přiřadit k okruhu stanic tzv. pomoravského aurignacienu s listovými hroty trojúhelníkového tvaru typu Lhota (Klíma 1978; 1979; Demidenko et al. 2018). Tento sídelní klastr si do budoucna zaslouží podrobnější zpracování. Dále by bylo vhodné připravit regionální studii věnovanou paleolitickému osídlení širšího okolí, které je doloženo bohatými povrchovými sběry.

\section{Poděkování}

Výzkum byl hrazen z prostředků investora, kterým byla firma Kamenolomy ČR, s. r. o. - Kamenolom Podhůra. Za pomoc s určením kamenných surovin patři dík prof. Antonínu Přichystalovi. 


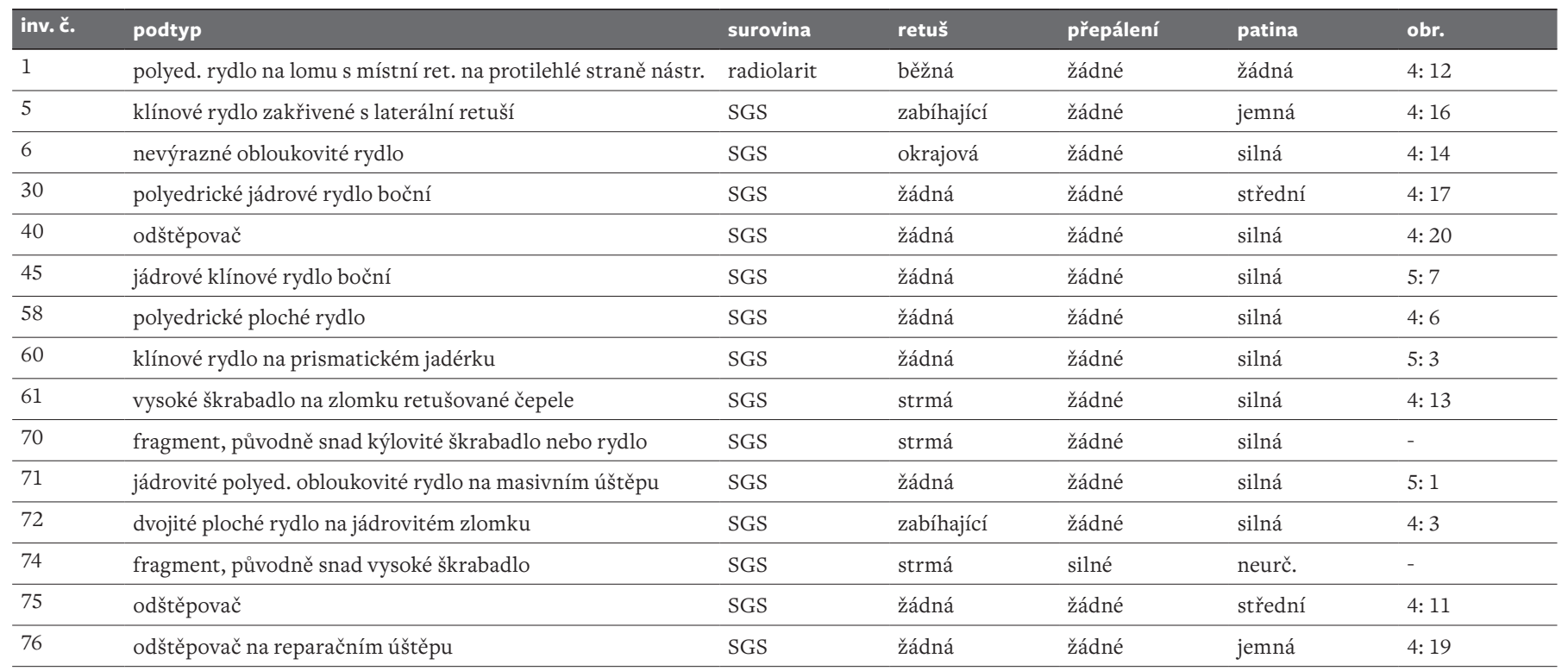

Tab. 4. Hlinsko - Kouty III. Soupis nalezených nástrojů.

Tab. 4. Hlinsko - Kouty III. A list of the excavated tools.

\section{Literatura}

Demidenko, Y. E., Škrdla, P., Rios-Garaizar, J. 2018: The Hlinsko Kouty I site and the only stratified Aurignacian-like assemblage with a bifacial triangular point in Moravia. Přehled výzkumů 59(1), 17-34.

Diviš, J., Fryč, D. 2011: Přehled archeologických lokalit a nálezů objevených a zkoumaných členy archeologického klubu v Př́íboře. Archeologie Moravy a Slezska 2011, 117-136.

Figel', D., Schenk, Z., Škrdla, P. 2009: Hlinsko (okr. Přerov). Přehled výzkumů 50, 226-229.

Fryč, J. 1981: Lhota u Lipníka. In: Archeologické nálezy vypovídají, 10 let činnosti kroužku dopisujících členü ČSSA v Příboře při DK ROH. Příbor: Dům kultury ROH, 9-28.

Jelínková, R. 2005: Lhota (k. ú. Lhota u Lipníku nad Bečvou, okr. Přerov). Přrehled výzkumů 46, 189-197.

Klíma, B, 1978: Paleolitická stanice u Přestavlk, okr. Přerov. Archeologické rozhledy XXX(1), 5-13.

Klíma, B. 1979: Nová stanice aurignacienu v Moravské bráně. Archeologické rozhledy XXXI(4), 361-369.

Klíma, B. 1980: Nová paleolitická stanice s křemencovou industrií od Pavlovic u Přerova. Anthropozoikum N. S. 13, 149-170.

Pavelčík, J. 2001: Hlinsko. Hradisko bádenské kultury. Archeologické památky střední Moravy 2. Olomouc: Vlastivědné muzeum.

Přichystal, A. 1980: Pavlovice u Přerova - další paleolitická stanice v Moravské bráně. Zprávy Krajského vlastivědného muzea v Olomouci 208, 30-32.

Přichystal, A. 2009: Kamenné suroviny v pravěku východní části střrední Evropy. Brno: Masarykova univerzita.

Šebela, L. a kol. 2007: Hlinsko. Výšinná osada lidu badenské kultury. Spisy Archeologického ústavu AV ČR Brno 32. Brno: Archeologický ústav AV ČR, Brno, v. v. i.

Škrdla, P. 2006: Hlinsko (okr Přerov). Přehled výzkumů 47, 84-85. Škrdla, P. 2007: Hlinsko (okr. Přerov). Přehled výzkumů 48, 310-313.

\section{Summary}

A collection of 88 Upper Palaeolithic artefacts has been excavated during a rescue excavation conducted by the Archaeological Centre in Olomouc at Hlinsko - Kouty III. This site is located in central Moravia near Lipník nad Bečvou on the periphery of a greywacke mine, about $350 \mathrm{~m}$ to the west of another Palaeolithic site excavated by P. Škrdla in 2006 and 2008 (Škrdla 2007; Demidenko et al. 2018; Fig. 1). The excavation took place due to the expansion of a mine. In addition to the Upper Palaeolithic settlement, two Eneolithic barrows were also excavated in this area (cf. Eneolithic chapter of this volume).

Most of the lithics were made of erratic flint, however some artefacts were also made of radiolarite, spongolite, local chert and quartzite (Tab. 1). Cores were usually prismatic, intended for blade and bladelet production (Tab. 3; Fig. 5). Fifteen tools were present (Tab. 4). Dihedral and carinated burins with multiple facets were the most numerous type (Fig. 4: 6, 12 and 17), although flat burins (Fig. 4:3 a 6) and nuclear burins (Fig. 5: 1, 3 and 7) were also present. Other tools included a high endscraper made on a laterally retouched blade fragment (Fig. 4: 13) and three splintered pieces (Fig. 4: 11, 19 and 20). Based on these finds, the assemblage can be classified as a developed (perhaps late) Aurignacian. Although a bifacial triangular point was not found during this excavation, it is probable that this collection belongs to the Aurignacian-like industries characterised by bifacial triangular points, which are known mostly from surface sites in the surrounding area. One specimen of this type and a fragment of another were found at the nearby Hlinsko - Kouty I (Demidenko et al. 2018). The lithic collection originating from this site is otherwise very similar and perhaps it is associated with the neighbouring sites forming a settlement cluster from the same period.

\section{Kontakt}

Ondřej Mlejnek

Archeologické centrum Olomouc

U Hradiska 42/6

CZ-779 00 Olomouc

mlejnek.o@seznam.cz 
